\title{
Isolation and preliminary evaluation of Mulva Neglecta mucilage: a novel tablet binder
}

\author{
Haroon Rahim1,", Abdul Sadiq², Shahzeb Khan², Kamran Ahmad Chishti', Fazli Amin", \\ Mir Azam Khan², Sudhair Abbas ${ }^{1}$
}

\begin{abstract}
${ }^{1}$ Department of Pharmacy, Sarhad University of Science and Information Technology Peshawar, Khyber Pakhtunkhwa, Pakistan, ${ }^{2}$ Department of Pharmacy, University of Malakand, Khyber Pakhtunkhwa, Pakistan
\end{abstract}

\begin{abstract}
The aim of this study was to evaluate binding potential of Mulva neglecta mucilage (MNM) with subsequent comparison to PVP K30. Eight batches of Diclofenac sodium tablets were prepared by wet granulation technique keeping different concentrations $(4,6,8 \& 10 \% \mathrm{w} / \mathrm{w})$ of Mulva neglecta mucilage (extracted from leaves of Mulva neglecta) and PVP K30 as standard binder. The granules of formulated batches showed bulk density $(\mathrm{g} / \mathrm{mL}) 0.49 \pm 0.00$ to $0.57 \pm 0.00$, tapped density $(\mathrm{g} / \mathrm{mL}) 0.59 \pm 0.01$ to $0.70 \pm 0.01$, Carr's index $09.27 \pm 0.95$ to $19.65 \pm 0.59$, Hausner's ratio $1.12 \pm 0.00$ to $1.24 \pm 0.01$ and angle of repose $30.37 \pm 2.90{ }^{\circ} \mathrm{C}$ to $36.86 \pm 0.94{ }^{\circ} \mathrm{C}$. Tablets were compressed to hardness 7.50 to $7.95 \mathrm{~kg} / \mathrm{cm}^{2}$. The tablets showed $0.39 \pm 0.02$ to $0.39 \pm 0.01 \%$ friability and 7:20 to $14: 00$ min disintegration time. Granules and post-compression evaluation revealed that parameters assessed were all found to be within the pharmacopoeial limits. The results (hardness, disintegration and dissolution) proved that Mulva neglecta mucilage has better binding capacity for preparation of uncoated tablet dosage form as compared to PVP K30. Among all the formulations, MN-1 to MN-4 showed slow release as compared to PV-1 to PV-4 and thereby Mulva neglecta mucilage exhibited satisfactory drug release phenomenon tablets of diclofenac sodium.
\end{abstract}

Uniterms: Mulva neglecta/mucilage. Mulva neglecta/use as binder. Binders. Diclofenac sodium/tablets/ drug release.

O objetivo deste estudo foi avaliar o potencial de ligação de mucilagem de Mulva neglecta (MNM), com posterior comparação ao PVP K30. Oito lotes de comprimidos de diclofenaco de sódio foram preparados pela técnica de granulação úmida, mantendo diferentes concentrações $(4,6,8$ e 10\% w/w) de mucilagem de Mulva neglecta (extraída de folhas de Mulva neglecta) e PVP K30 como ligante padrão. Os grânulos de lotes formulados mostraram densidade aparente $(\mathrm{g} / \mathrm{mL}) 0.49 \pm 0.00-0.57 \pm 0.00$, densidade compactada $(\mathrm{g} / \mathrm{mL}) \quad 0.59 \pm 0.01-0.70 \pm 0.01$, índice de Carr 09.27 $\pm 0.95-19.65 \pm 0.59$, a relação de Hausner $1.12 \pm 0.00-1.24 \pm 0.01$ e ângulo de repouso $30.37 \pm 2.90{ }^{\circ} \mathrm{C}$ a $36.86 \pm 0.94{ }^{\circ} \mathrm{C}$. Os comprimidos foram prensados à dureza de $7.50-7.95 \mathrm{~kg} / \mathrm{cm}^{2}$. Os comprimidos apresentaram $0.39 \pm 0.02-0.39 \pm 0.01 \%$ friabilidade e 7:20-14:00 min de tempo de desintegração. A avaliação de grânulos e pós-compressão revelou que todos os parâmetros estavam dentro dos limites da farmacopeia. Os resultados (dureza, desintegração e dissolução) provaram que a mucilagem de Mulva neglecta tem maior capacidade de ligação na preparação da forma de dosagem de comprimido não revestido em relação à PVP K30. Entre todas as formulações, MN-1 e MN-4 mostraram liberação lenta em comparação com PV-1 e PV-4 e, assim, a mucilagem de Mulva neglecta exibiu liberação do fármaco satisfatória para os comprimidos de diclofenaco de sódio.

Unitermos: Mulva neglecta/mucilagem. Mulva neglecta/uso como aglutinante/avaliação. Aglutinantes. Diclofenaco de sódio/comprimidos/liberação do fármaco.

*Correspondence: Haroon Rahim. Department of Pharmacy. Sarhad University of Science and Information Technology, Peshawar, Khyber Pakhtunkhwa, Pakistan. E-mail: hrahimpk@gmail.com 


\section{INTRODUCTION}

Natural plant drugs and excipients have gained attractiveness over synthetic materials due to their nontoxic nature, free availability and low cost (Zohra et al., 2012). Mucilages are widely used in pharmaceutical preparations as thickening, disintegrating, binding, suspending, emulsifying, gelling and stabilizing agents (Malviya et al., 2010). Mulva neglecta Wallr. (Mulvaceae), commonly known as Mallow and locally 'Sonchal' in Mansehra, Pakistan. This is a perennial plant having leaves very shallowly lobed, crenate and pilose (Akcin, Ozbucak 2006; Shah, Khan, 2006). The plant is used as food and to treat acne, broken bones, dermatitis, burns and throat infection (Imtiaz et al., 2012). Diclofenac sodium is a non-steroidal anti-inflammatory drug (NSAID), which is poorly soluble in water and freely soluble in organic solvent like methanol. It is commonly used as analgesic, antipyretic, anti-inflammatory for the long-term treatment of rheumatoid arthritis. Its structure is shown in Figure 1 (Ganesh et al., 2010).

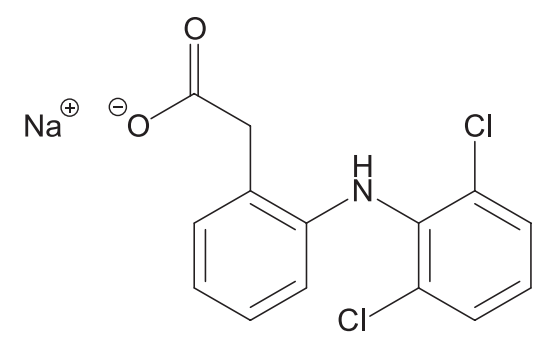

FIGURA 1 - Chemical structure of diclofenac sodium.

In view of the easy availability of plant, the mucilage from the leaves of the plant was investigated for its use in tablets formulation and evaluates its efficiency as binder.

\section{MATERIAL AND METHODS}

\section{Material}

Diclofenac sodium, Avicel pH 101, Aerosil, magnesium stearate and PVP K30 were provided by Prays Pharmaceuticals (Pvt) Ltd, Islamabad, Pakistan. Mulva neglecta mucilage was extracted from leaves of plant (Mulva neglecta).

\section{Extraction of the mucilage}

Fresh Mulva neglecta plants (10 kg) were purchased from local market. The plant was identified by Prof. Dr. Jehandar Shah, Ex-Vice Chancellor, Shaheed Benazir Bhutto University, Sheringal (Dir Upper) Khyber Pakhtunkhwa, Pakistan. The specimen sample (PM-0612) was kept in Department of Pharmacy, University of Malakand, Chakdara, Dir Lower, Khyber Pakhtunkhwa, Pakistan. The fresh leaves of the plant were collected, washed with water to remove dirt and debris, and dried. The powdered leaves were soaked in water for 4-5 h, boiled for $30 \mathrm{~min}$ and then kept aside for $1 \mathrm{~h}$ for complete release of the mucilage into water. The material was squeezed, to remove extraneous materials, by straining through a muslin cloth. The mucilage was then precipitated from the solution using absolute acetone. The precipitate was separated, dried in oven at $50^{\circ} \mathrm{C}$ and stored in tightly closed container for future use in tablets formulations.

\section{Preliminary phytochemical of mucilage}

The phytochemical properties for the presence of carbohydrates, proteins, flavonoids, sterols, alkaloids, tannins, saponins, resins, phenols and terpenoids were determined as per standard tests (Cokate, 2010).

\section{Physicochemical characterization}

The isolated mucilage was evaluated for solubility in water, acetone, chloroform and ethanol in accordance with the official monograph specifications, swelling index, loss on drying, total ash and acid-insoluble ash determination (Patel et al., 2012).

\section{Toxicity studies of Mulva neglecta mucilage}

Toxicity studies were carried out according to the method of Knudsen and Curtis. The animals used in the toxicity studies were sanctioned by the Experimental protocols were in compliance with "Animals Byelaws 2008 of the University of Malakand". Ethical Committee of the Department of Pharmacy, University of Malakand approved the experimental protocols. The male albino rats of Wistar strain with average weight of 160-200 g were divided into different groups comprising of six animals in each group. The control group received normal saline $20 \mathrm{~mL} / \mathrm{kg}$ intraperitoneal (i.p). The other groups received $500,1000,2000,3000$ and $4000 \mathrm{mg} / \mathrm{kg}$ of mucilage suspension in normal saline orally. The animals were observed continuously for the behavioral changes for the first $4 \mathrm{~h}$ and then observed for mortality for $48 \mathrm{~h}$ (Shah, Patel, 2010). 


\section{Preparation and evaluation of granules}

The compositions of tablets are given in Table 4 . Diclofenac sodium and Avicel pH 101 were thoroughly mixed and the solutions of the mucilage and PVP K30 (prepared by dispersing the mucilage and PVP K30 in water) of different concentrations $(4,6,8 \& 10 \% \mathrm{w} / \mathrm{w})$ were used for moistening the powder mixture to prepare tablets. The wet mass was then passed through sieve No. 16 and dried at temperature not exceeding $60{ }^{\circ} \mathrm{C}$ in hot air oven up to LOD NMT 5\%. The dried granules were re-sieved through sieve No. 20. The same procedure was followed for preparation of granules using PVP K30 as binder.

\section{Bulk density}

Granules of known weight were poured in $10 \mathrm{ml}$ graduated cylinder, bulk volume $\left(\mathrm{V}_{0}\right)$ was noted and bulk density was calculated $(\mathrm{g} / \mathrm{cc})$ by the given formula (Ganesh, Sureshkumar et al. 2010):

$$
\text { Bulk Density }=\frac{\text { Weight of granules }}{\text { Bulk volume }}
$$

\section{Tapped density}

The graduated cylinder $(10 \mathrm{ml})$ containing known weight of granules was tapped on a hard surface until no further change in volume was observed. The tapped volume $\left(\mathrm{V}_{\mathrm{T}}\right)$ was noted and tapped density was calculated by putting values in formula, Weight of granules/ $\mathrm{V}_{\mathrm{T}}$ (Ganesh et al., 2010).

\section{Compressibility index}

It was determined by Carr's compressibility index, by formula:

$$
\text { Compressibility index }=\frac{T_{d}-B_{d}}{T_{d}} \times 100
$$

where $T_{d}$ is tapped density and $B_{d}$ is bulk density.

\section{Hausner's ratio}

It is the ratio of tapped density to bulk density and was calculated by the following formula (Chakraverty, 2011):

$$
\text { Hausner's ratio }=\frac{T_{d}}{B_{d}}
$$

where $T_{d}$ is tapped and $B_{d}$ is bulk density.
Angle of repose $\left(^{\circ}\right)$

It was determined by filling $10 \mathrm{~g}$ of powder in a funnel. Then the funnel was opened to release the powder on the paper to form a conical heap. The values were calculated by the given formula (Chakraverty, 2011).

$$
\tan \theta=\frac{\mathrm{h}}{\mathrm{r}} \text { or } \theta=\tan ^{-1} \frac{\mathrm{h}}{\mathrm{r}}
$$

\section{Compression of Granules/ Preparation of tablets}

The granules were then into tablets using rotary machine (ZP19 Rotary Tablet Press, Shanghai, China).

\section{Evaluation of tablets}

\section{Thickness}

The thickness of a tablet can vary without any change in its weight. This is generally due to the difference of density of granules, pressure applied for compression and the speed of compression. The thickness of the tablets was determined by using a Digital Caliper (Shingala et al., 2010).

\section{Uniformity of weight}

Twenty tablets were weighed by analytical balance (Sartorius BL 2105, Germany) after compression, then average weight and standard deviation was determined. Then determine the percentage of weight variation of each tablet by using following formula (Rahim et al., 2014).

Percentage of weight variation $=\frac{\text { Average weight }- \text { Individual weight }}{\text { Average weight }} \times 100$

\section{Drug contents determination}

Tablets (10) were accurately weighed and powdered. Powder amount equivalent to $50 \mathrm{mg}$ diclofenac sodium was shaken with $60 \mathrm{~mL}$ of methanol in a $200 \mathrm{~mL}$ volumetric flask and final volume was make up with methanol, $5 \mathrm{~mL}$ of this solution was further diluted to $100 \mathrm{~mL}$ with methanol and absorbance was measured using spectrophotometer (UV-1601 Shimadzu, Japan) at $276 \mathrm{~nm}$. The content was determined by preparing same concentration of sodium diclofenac in the same solvent and absorbance was measured at $276 \mathrm{~nm}$. The \% content was determined by formula (Rahim et al., 2014):

$\%$ Drug content $=\frac{\text { Absorbance of sample } \times \text { Average weight of tablet }}{\text { Absorbance of standard } \times \text { weight of sample }} \times 100$

\section{Friability}

The friability of tablets was determined using Roche Friabilator. Ten tablets were initially weighed $\left(\mathrm{W}_{1}\right)$ and 
transferred into the friabilator. The friabilator was operated at $25 \mathrm{rpm}$ for $4 \mathrm{~min}$, or alternatively was run up to 100 revolutions. The tablets were weighed again $\left(\mathrm{W}_{2}\right)$ and the $\%$ friability was calculated (Chakraverty, 2011).

$$
\% \text { Friability }=\frac{\left(\mathrm{W}_{1}-\mathrm{W}_{2}\right)}{\mathrm{W}_{1}} \times 100
$$

where $\mathrm{W}_{1}$ = initial weight of 10 tablets, and $\mathrm{W}_{2}=$ weight of 10 tablets after 100 revolutions

\section{Disintegration time}

The method specified in the USP/NF (2007) was followed for disintegration time, medium used was 100 $\mathrm{mL}$ of $0.1 \mathrm{~N} \mathrm{HCl}$ maintained at temperature between $37 \pm 2{ }^{\circ} \mathrm{C}$ throughout the experiment. Five tablets were randomly selected from each batch and were placed one in each of the cylindrical tubes of the basket using disintegration test apparatus (DT-0607, Curio) but no disc was used. The time taken for each tablet to break up into small particles and pass out through the mesh was noted (Satyam et al., 2010).

\section{In vitro dissolution studies}

An in vitro release study was carried out using USP XXIV 8 station dissolution rate test apparatus, using $900 \mathrm{~mL}$ of phosphate buffer $\mathrm{pH} 6.8$ for a period of $1 \mathrm{~h}$ at $50 \mathrm{rpm}$ with maintained temperature at $37 \pm 0.5{ }^{\circ} \mathrm{C}$. Samples $(5 \mathrm{~mL})$ were withdrawn at pre determined intervals over $1 \mathrm{~h}$ using a syringe filter of 0.2 micron and $5 \mathrm{~mL}$ of fresh dissolution medium was replaced after each sampling in order to maintain sink condition The collected samples were analysed by spectrophotometer at $276 \mathrm{~nm}$ (Rajesh, Venkataraju, Gowda, 2009).

\section{FTIR studies}

To study any possible interaction between drug and the plant mucilage used, FTIR spectroscopic analysis was carried out. The drug, plant mucilage and formulation blend (mixture containing Diclofenac sodium, Mulva neglecta mucilage, Avicel pH 101 and magnesium stearate) compatibility were studied by using IR spectrophotometer (Nicolet FTIR spectrophotometer, Thermoscientific Nicolet, USA). A small amount of Diclofenac sodium, plant mucilage and formulation blend were respectively placed directly on the germanium piece of the infrared spectrometer with constant pressure applied and data of infrared absorbance collected over the wave number ranged from $4000 \mathrm{~cm}^{-1}$ to $400 \mathrm{~cm}^{-1}$ and was expressed in $\mathrm{cm}^{-1}$ (Bobby, Wesely, Johnson et al., 2012).

\section{RESULTS AND DISCUSSION}

\section{Phytochemical screening}

Phytochemical investigation of the isolated mucilage showed the presence of carbohydrates and flavonoids while absence of proteins, tannins, saponins, sterols, alkaloids and glycosides. The results are shown in Table I.

TABLE I - Phytochemical screening of Mulva neglecta mucilage

\begin{tabular}{lc}
\hline Active Constituent & MNM \\
\hline Carbohydrate & $+\mathrm{ve}$ \\
Protein & $-\mathrm{ve}$ \\
Flavanoids & $+\mathrm{ve}$ \\
Tannins & $-\mathrm{ve}$ \\
Saponins & $-\mathrm{ve}$ \\
Sterols & $-\mathrm{ve}$ \\
Alkaloids & $-\mathrm{ve}$ \\
Glycosides & $-\mathrm{ve}$ \\
\hline
\end{tabular}

+ve means Present, -ve means Absent

\section{Organoleptic and physicochemical properties}

The Organoleptic properties were found acceptable and are summarized in Table II. It showed the presence of mucilage by ruthenium red test with $10-20 \%$ yield, yellowish brown colour, bland taste and coarse appearance. The solubility analysis reveals that Mulva neglecta mucilage is sparingly soluble in cold water however it showed solubility when the temperature of water was increased. The mucilage was completely insoluble in the tested organic solvents including ethanol, chloroform, acetone and benzene. Physicochemical screenings indicate $\mathrm{pH}$ $(1 \% \mathrm{w} / \mathrm{w}$ solution $)$ of the isolated mucilage was found 5.45 at $28^{\circ} \mathrm{C}$ which indicate that this mucilage was less irritating in GIT and suitable for uncoated tablet. The moisture content, swelling index and loss on drying were 7,35 and $11 \%$ respectively. The total ash and acid insoluble ash value of MNM was found to be $0.974 \pm 0.011$ and $0.013 \pm 0.003 \% \mathrm{w} / \mathrm{w}$ respectively. Ash values reflect the level of adulteration of drug. Adulteration by sand or earth is immediately detected as the total ash is normally composed of inorganic mixtures of carbonates, phosphates, silicates and silica.

The physicochemical properties of granules of Mulva neglecta mucilage are shown in Table III. The prepared granules were evaluated for flow properties. The 
TABLE II - Organoleptic properties of Mulva neglecta mucilage

\begin{tabular}{|c|c|}
\hline Parameters & Results \\
\hline Test for mucilage (Ruthenium Red test) & $+\mathrm{ve}$ \\
\hline Yield $(\%)$ & $10-20$ \\
\hline Color & Yellowish Brown \\
\hline Taste & Bland \\
\hline Texture & Moderately coarse \\
\hline Solubility & $\begin{array}{l}\text { Sparingly Soluble in } \\
\text { cold water, soluble } \\
\text { in hot water forming } \\
\text { viscous colloidal } \\
\text { solution, insoluble in } \\
\text { ethanol, chloroform, } \\
\text { acetone and benzene }\end{array}$ \\
\hline Moisture content $(\%)$ & 7 \\
\hline Swelling index $(\%)$ & 35 \\
\hline $\mathrm{pH}(1 \% \mathrm{w} / \mathrm{w}$ solution $)$ at $28^{\circ} \mathrm{C}$ & 5.45 \\
\hline Viscosity $(1 \% \mathrm{w} / \mathrm{w}$ solution $) \mathrm{m}$ Pas & 3.80 \\
\hline Loss on drying $(\%)$ & 11 \\
\hline Total ash $(\%)$ & $0.974 \pm 0.011$ \\
\hline Acid insoluble ash $(\%)$ & $0.013 \pm 0.003$ \\
\hline
\end{tabular}

All values are mean \pm S.D. for $n=3$

Carr's index values were found in range from $09.27 \pm 0.59$ to $19.65 \pm 0.59$ while angle of repose values resulted were $30.37 \pm 2.90$ to $36.86 \pm 0.94$. The results showed that granules have good flow properties.

To determine the safety level of the extracted Mulva neglecta mucilage, acute toxicity study was carried out. In this study, the mucilage revealed no behavioral changes for first four hours and no mortality was observed in animal being tested. Toxicity studies showed no mortality, no toxic manifestations were observed and behavioural pattern was unaffected. The mucilage is therefore safe to be used in formulations.

Formulation of diclofenac sodium tablet by wet granulation method containing Mulva neglecta mucilage as a binder is shown in Table IV.

Three batches of the tablets prepared for each gum in different concentrations were evaluated for parameters like hardness $\left(\mathrm{kg} / \mathrm{cm}^{2}\right)$, friability $(\%)$, weight variation $(\%)$, disintegration time (min), thickness (\%) and drug content $(\%)$. Hardness was found in range of $7.50 \pm 0.63$ to $7.9 \pm 0.68 \mathrm{~kg} / \mathrm{cm}^{2}$. The friability values were in the range from $0.39 \pm 0.02$ to $0.69 \pm 0.01 \%$, i.e. values are less than $1 \%$ and are in the acceptable range. Weight variation $(200.80 \pm 3.24$ to $202.15 \pm 1.32 \%)$ were within limit $( \pm 7.5 \%)$, disintegration time was less than 15 min fulfilling the pharmacopoeial limits for uncoated tablets and the drug content ranged from $99.44 \pm 0.70$ to $100.99 \pm 1.10$ (limit is $90-110 \%$ ). Mulva neglecta based tablets showed increase in hardness as compared to PVP K30 as binder. Rapid disintegration was observed in PVP K30 containing batches of tablets when compared with Mulva neglecta as binder. All these results are summarized in Table V.

\section{In vitro dissolution studies}

In vitro release studies was carried out using USP XXIV 8 station dissolution rate test apparatus using $900 \mathrm{~mL}$ of phosphate buffer ( $\mathrm{pH}$ 6.8) for a period of $1 \mathrm{~h}$ at $50 \mathrm{rpm}$ and the temperature was maintained at $37 \pm 1{ }^{\circ} \mathrm{C}$. By withdrawing samples each of $5 \mathrm{~mL}$ at $10 \mathrm{~min}$ intervals over $1 \mathrm{~h}$ and analyzed using spectrophotometer at 276 $\mathrm{nm}$. It is shown in the dissolution plot that $\mathrm{MN}-1$ and

TABLE III - Physicochemical properties of granules

\begin{tabular}{lccccc}
\hline $\begin{array}{l}\text { Formulations } \\
\text { with Code }\end{array}$ & $\begin{array}{c}\text { Bulk density } \\
(\mathbf{g} / \mathbf{m L})\end{array}$ & $\begin{array}{c}\text { Tapped density } \\
(\mathbf{g} / \mathbf{m L})\end{array}$ & Carr's index & Hausner's ratio & $\begin{array}{c}\text { Angle Repose } \\
\left({ }^{\circ}\right)\end{array}$ \\
\hline MN-1 & $0.49 \pm 0.00$ & $0.59 \pm 0.01$ & $16.19 \pm 0.53$ & $1.18 \pm 0.00$ & $31.30 \pm 0.12$ \\
MN-2 & $0.53 \pm 0.01$ & $0.60 \pm 0.00$ & $10.96 \pm 0.01$ & $1.12 \pm 0.00$ & $34.76 \pm 0.04$ \\
MN-3 & $0.56 \pm 0.00$ & $0.63 \pm 0.00$ & $10.98 \pm 0.01$ & $1.12 \pm 0.00$ & $35.14 \pm 0.24$ \\
MN-4 & $0.57 \pm 0.00$ & $0.63 \pm 0.01$ & $09.27 \pm 0.59$ & $1.09 \pm 0.01$ & $32.10 \pm 0.31$ \\
PV-1 & $0.52 \pm 0.01$ & $0.59 \pm 0.00$ & $12.00 \pm 0.20$ & $1.13 \pm 0.01$ & $33.44 \pm 1.06$ \\
$\mathbf{P V - 2}$ & $0.57 \pm 0.00$ & $0.70 \pm 0.01$ & $19.65 \pm 0.59$ & $1.24 \pm 0.00$ & $36.86 \pm 0.94$ \\
$\mathbf{P V - 3}$ & $0.54 \pm 0.07$ & $0.61 \pm 0.01$ & $10.00 \pm 0.13$ & $1.12 \pm 0.01$ & $32.43 \pm 1.03$ \\
$\mathbf{P V - 4}$ & $0.56 \pm 0.01$ & $0.64 \pm 0.03$ & $11.99 \pm 0.51$ & $1.13 \pm 0.01$ & $30.37 \pm 2.90$ \\
\hline All
\end{tabular}

All values represent mean \pm S.D, $n=3$. Key: S.D means standard deviation 
TABLE IV - Formulation of diclofenac sodium tablets by wet granulation method

\begin{tabular}{lcccccccc}
\hline Ingredients (mg) & MN-1 & MN-2 & MN-3 & MN-4 & PV-1 & PV-2 & PV-3 & PV-4 \\
\hline Diclofenac sodium & 50 & 50 & 50 & 50 & 50 & 50 & 50 & 50 \\
Avicel pH 101 & 138 & 133 & 128 & 123 & 138 & 133 & 128 & 123 \\
Aerosil & 4 & 4 & 4 & 4 & 4 & 4 & 4 & 4 \\
MNM & 5 & 10 & 15 & 20 & --- & --- & --- & --- \\
PVP K30 & --- & --- & --- & --- & 5 & 10 & 15 & 20 \\
Magnesium stearate & 3 & 3 & 3 & 3 & 3 & 3 & 3 & 3 \\
Distilled water & q.s & q.s & q.s & q.s & q.s & q.s & q.s & q.s \\
\hline Total weight & 200 & 200 & 200 & 200 & 200 & 200 & 200 & 200 \\
\hline
\end{tabular}

TABLE V - Evaluation of diclofenac sodium tablets

\begin{tabular}{|c|c|c|c|c|c|c|}
\hline Formulations & $\begin{array}{c}\text { Hardness } \\
\left(\mathbf{k g} / \mathrm{cm}^{2}\right)\end{array}$ & $\begin{array}{c}\text { Friability } \\
(\%)\end{array}$ & $\begin{array}{c}\text { Weight variation } \\
(\%)\end{array}$ & $\begin{array}{l}\text { D. Time } \\
\text { (min) }\end{array}$ & $\begin{array}{l}\text { Thickness } \\
\text { (mm) }\end{array}$ & $\begin{array}{c}\text { Assay } \\
(\%)\end{array}$ \\
\hline MN-1 & $7.50 \pm 0.63$ & $0.69 \pm 0.01$ & $200.80 \pm 3.24$ & 7.20 & $4.32 \pm 1.04$ & $99.44 \pm 0.70$ \\
\hline MN-2 & $7.88 \pm 0.52$ & $0.54 \pm 0.03$ & $200.30 \pm 3.15$ & 9.25 & $4.32 \pm 1.08$ & $100.00 \pm 1.16$ \\
\hline MN-3 & $7.95 \pm 0.68$ & $0.42 \pm 0.04$ & $200.80 \pm 3.22$ & 11.05 & $4.31 \pm 1.12$ & $100.34 \pm 1.21$ \\
\hline MN-4 & $7.91 \pm 0.45$ & $0.39 \pm 0.02$ & $200.90 \pm 3.14$ & 14.20 & $4.36 \pm 1.13$ & $99.65 \pm 1.00$ \\
\hline PV-5 & $7.83 \pm 0.56$ & $0.69 \pm 0.01$ & $201.50 \pm 3.17$ & 6.10 & $4.34 \pm 1.03$ & $100.00 \pm 0.20$ \\
\hline PV-6 & $7.94 \pm 0.63$ & $0.62 \pm 0.02$ & $200.75 \pm 3.32$ & 8.13 & $4.30 \pm 0.91$ & $100.99 \pm 1.10$ \\
\hline PV-7 & $7.77 \pm 0.51$ & $0.53 \pm 0.01$ & $200.15 \pm 2.25$ & 11.17 & $4.34 \pm 1.09$ & $100.82 \pm 1.08$ \\
\hline PV-8 & $7.65 \pm 0.65$ & $0.46 \pm 0.02$ & $202.15 \pm 1.32$ & 14.00 & $4.31 \pm 1.13$ & $100.37 \pm 1.46$ \\
\hline
\end{tabular}

All the values are expressed as mean \pm SD

MN-2 released $95.21 \%$ and $76.88 \%$ respectively at the end of $30 \mathrm{~min}$, and $\mathrm{MN}-3$ and $\mathrm{MN}-4$ released $78.11 \%$ and $68.47 \%$ respectively at the end of $50 \mathrm{~min}$. PV-1 and PV-2 released $99.62 \%$ and $86.99 \%$ respectively at the end of 30 min while batches PV-3 and PV-4 released $94.80 \%$ and $89.26 \%$ respectively at the end of $50 \mathrm{~min}$. All the results of in vitro release of diclofenac sodium tablets are represented in Table VI.

The data showed that increase in concentrations of binder retard the rate of dissolution of drug from tablets.

TABLE VI - In vitro release of diclofenac sodium tablets

\begin{tabular}{lcccccccc}
\hline Time (min) & MN-1 & MN-2 & MN-3 & MN-4 & PV-1 & PV-2 & PV-3 & PV-4 \\
\hline 10 & 32.850 & 24.283 & 15.338 & 13.070 & 32.850 & 27.212 & 19.181 & 17.448 \\
20 & 62.803 & 50.110 & 32.692 & 25.259 & 62.803 & 52.629 & 40.251 & 36.913 \\
30 & 95.212 & 76.881 & 49.511 & 41.228 & 99.622 & 86.992 & 56.188 & 52.976 \\
40 & 99.811 & 98.645 & 63.842 & 56.598 & 99.811 & 99.023 & 77.858 & 73.039 \\
50 & 99.811 & 98.645 & 78.110 & 68.472 & 99.811 & 99.023 & 94.803 & 89.259 \\
60 & 99.811 & 98.645 & 94.803 & 84.409 & 99.811 & 99.023 & 99.559 & 99.779 \\
\hline
\end{tabular}


By increasing the concentration (from $4 \%$ to $6 \%$ ) of Mulva neglecta mucilage, the drug release retarded $8.56 \%$ in 10 min. While concentration of PVP K30 (from $4 \%$ to $6 \%$ ) showed drug release delayed 5.63\%. By comparing drug release from tablets batches containing Mulva neglecta mucilage and PVP K30, it is clarified that release retarded by Mulva neglecta mucilage efficiently as compared to PVP K30.

\section{Release kinetics}

Different kinetic models (zero-order, first-order, Higuchi's, Hixson Crowell and Korsmeyer's equation) were applied to interpret the release profile (the order and mechanism of diclofenac sodium release) from tablet, as shown in Table VII. To study the mechanism of drug release from the tablets, the release data were fitted to zero-order, first-order, and Higuchi equation. However, two factors diminish the applicability of Higuchi's equation to matrix systems. This model fails to allow the influence of swelling of the matrix (upon hydration) and gradual erosion of the matrix. Therefore, the dissolution data were also fitted according to the well-known exponential equation (Korsmeyer equation), which is often used to describe the drug release behaviour from polymeric systems. The Korsmeyer's equation is given as follows:

$$
\log \left(\frac{M t}{M f}\right)=\log k+n \log t
$$

where, Mt is the amount of drug release at time t, Mf is the amount of drug release after infinite time, $\mathrm{k}$ is release rate constant incorporating structural and geometric characteristics of the tablet and $\mathrm{n}$ is the diffusional exponent indicative of the mechanism of drug release.

To clarify the release exponent for different batches of matrix tablets, the log value of percentage drug dissolved was plotted against log time for each batch according to the Korsmeyer's equation. A value of $n=0.45$ indicates Fickian (case I) release, $>0.45$ but $<0.89$ for non-Fickian (anomalous) release and $>0.89$ indicates super case II type of release. Case II generally refers to the erosion of the polymeric chain and anomalous transport (non-Fickian) refers to a combination of both diffusion and erosion controlled-drug release (Gutti, Kalra, 2012).

\section{Drug excipients compatibility studies}

Drug and excipients compatibilities studies were carried out by using IR spectroscopy. IR Spectra of Drug (diclofenac sodium) and tablets formulations containing Mulva neglecta mucilage and tablet formulation blend were analyzed. The studies revealed that there was no significant interaction between drug and batches containing plant gums. The FT-IR spectrum of diclofenac sodium (drug) showed characteristic peaks at 3381.1, 3251.3, $1588.2,1501.3,1442.7$ and $1346.9 \mathrm{~cm}^{-1}$ as shown in Figure 2. Mulva neglecta mucilage showed characteristic peaks at 3247.3, 2927.8, 1600.8, 1416.9 and $1018.5 \mathrm{~cm}^{-1}$ as shown in Figure 3. The FT-IR analysis of physical mixtures of diclofenac sodium including Mulva neglecta with other excipients is shown in Figure 4. Hence no major change in peaks of diclofenac sodium tablets formulations containing mucilage which confirm the compatibility of mucilage with drug and other excipients used.

TABLE VII - In vitro release kinetics of diclofenac sodium

Tablets using Mulva neglecta mucilage as binder

\begin{tabular}{|c|c|c|c|c|c|c|c|}
\hline \multirow{2}{*}{ Formulations } & \multirow{2}{*}{$\frac{\text { Zero Order }}{\mathrm{r}^{2}}$} & \multirow{2}{*}{$\frac{\text { First Order }}{\mathrm{r}^{2}}$} & \multirow{2}{*}{$\frac{\text { Higuchi }}{\mathrm{r}^{2}}$} & \multirow{2}{*}{$\frac{\text { Hixson Crowell }}{\mathrm{r}^{2}}$} & \multicolumn{2}{|c|}{ Korsmeyer } & \multirow{2}{*}{$\begin{array}{c}\text { Release } \\
\text { mechanism }\end{array}$} \\
\hline & & & & & $\mathrm{r}^{2}$ & $\mathrm{~N}$ & \\
\hline MN-1 & 0.7410 & 0.6890 & 0.7180 & 0.8570 & 0.8090 & 0.535 & non-Fickian \\
\hline MN-2 & 0.8520 & 0.7790 & 0.8190 & 0.8810 & 0.8760 & 0.696 & non-Fickian \\
\hline MN-3 & 0.9980 & 0.9180 & 0.6370 & 0.9420 & 0.6430 & 0.446 & Fickian \\
\hline MN-4 & 0.9980 & 0.9380 & 0.9900 & 0.9360 & 0.9820 & 0.913 & non-Fickian \\
\hline PV-1 & 0.7020 & 0.6660 & 0.6810 & 0.7360 & 0.7890 & 0.534 & non-Fickian \\
\hline PV-2 & 0.8030 & 0.7440 & 0.8830 & 0.8760 & 0.9200 & 0.761 & non-Fickian \\
\hline PV-3 & 0.9780 & 0.8960 & 0.9784 & 0.9580 & 0.5820 & 0.399 & Fickian \\
\hline PV-4 & 0.9930 & 0.9120 & 0.9820 & 0.9130 & 0.9730 & 0.853 & non-Fickian \\
\hline
\end{tabular}




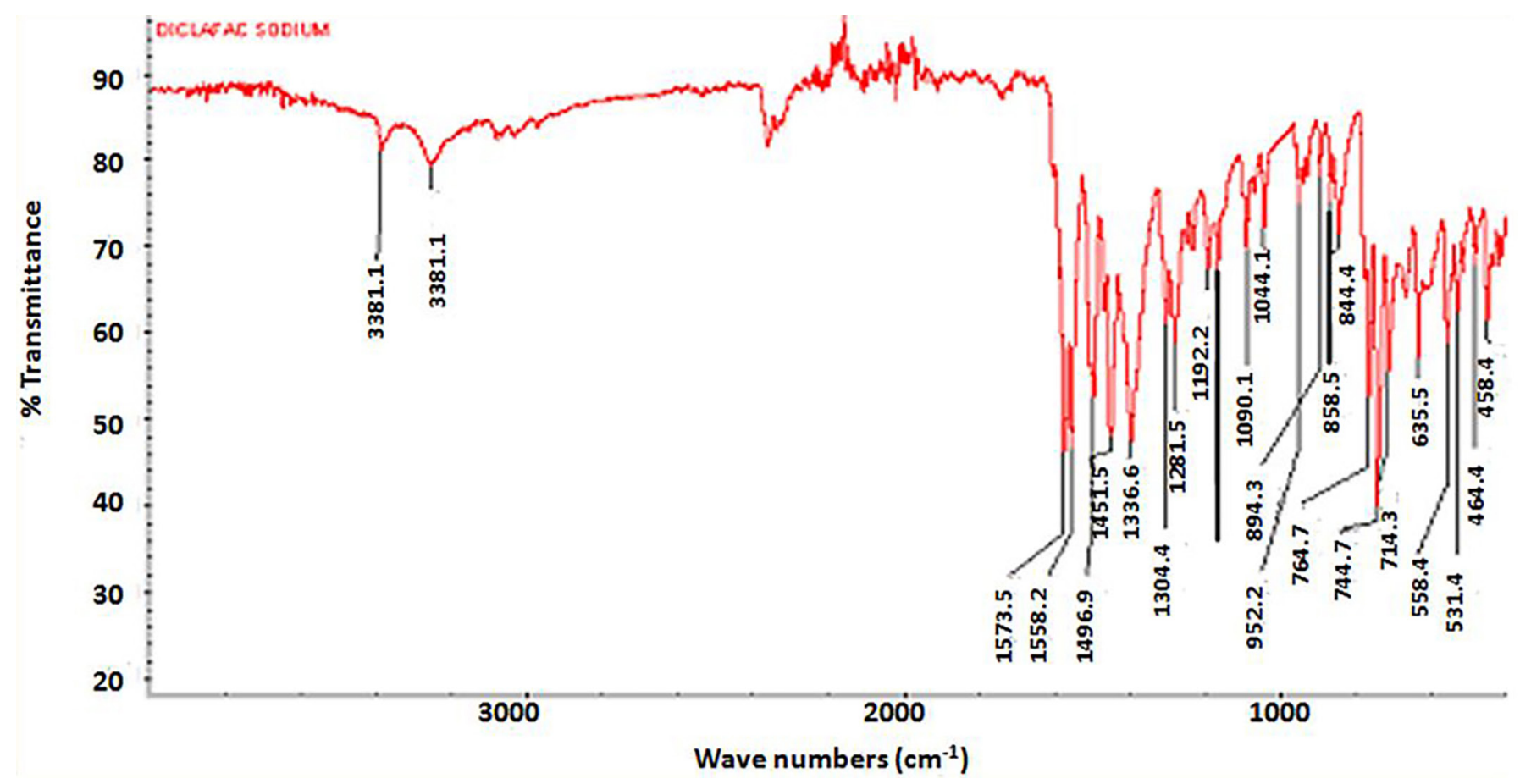

FIGURA 2 - FTIR Spectrum of diclofenac sodium.

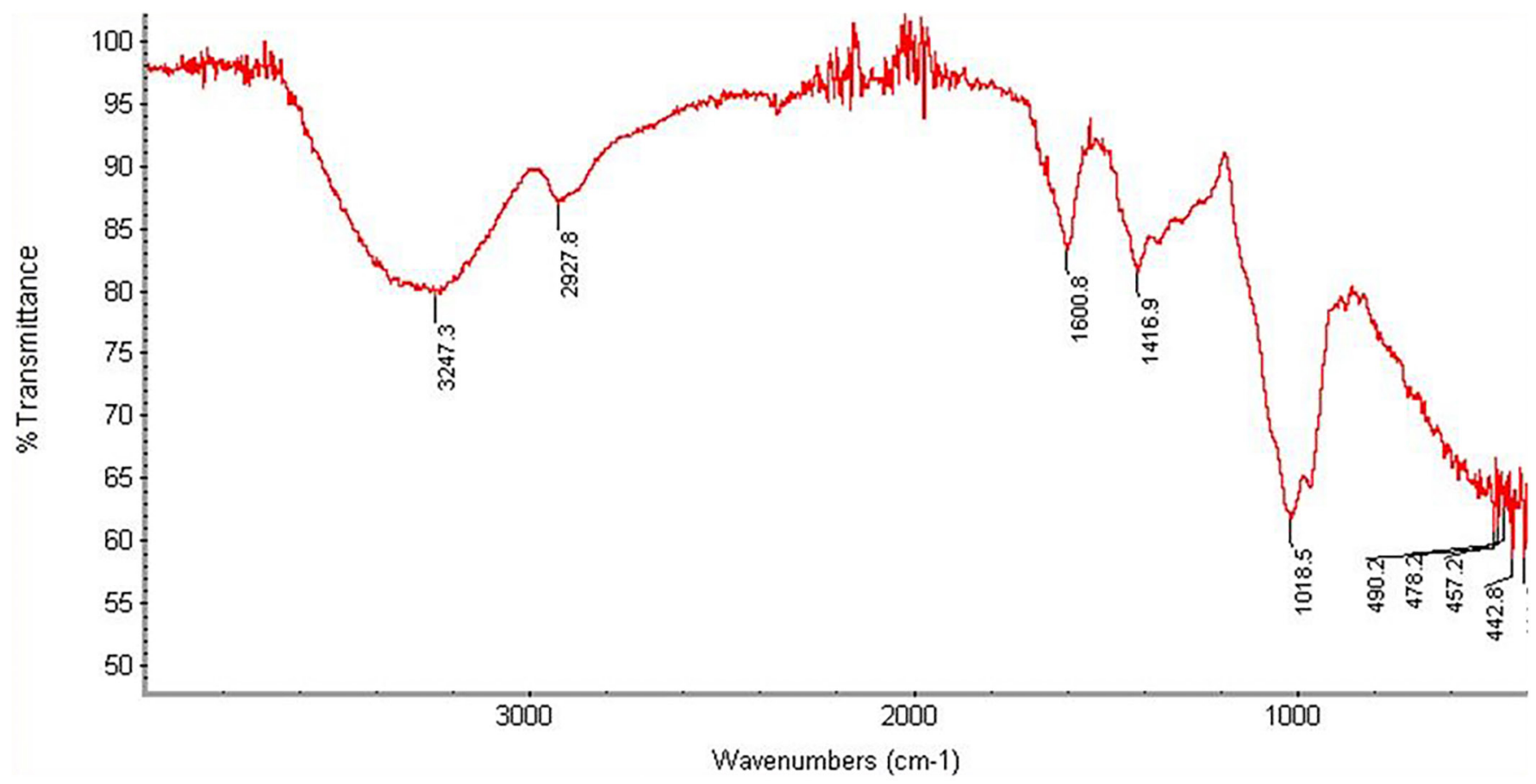

FIGURA 3 - FTIR Spectrum of Mulva neglecta mucilage. 


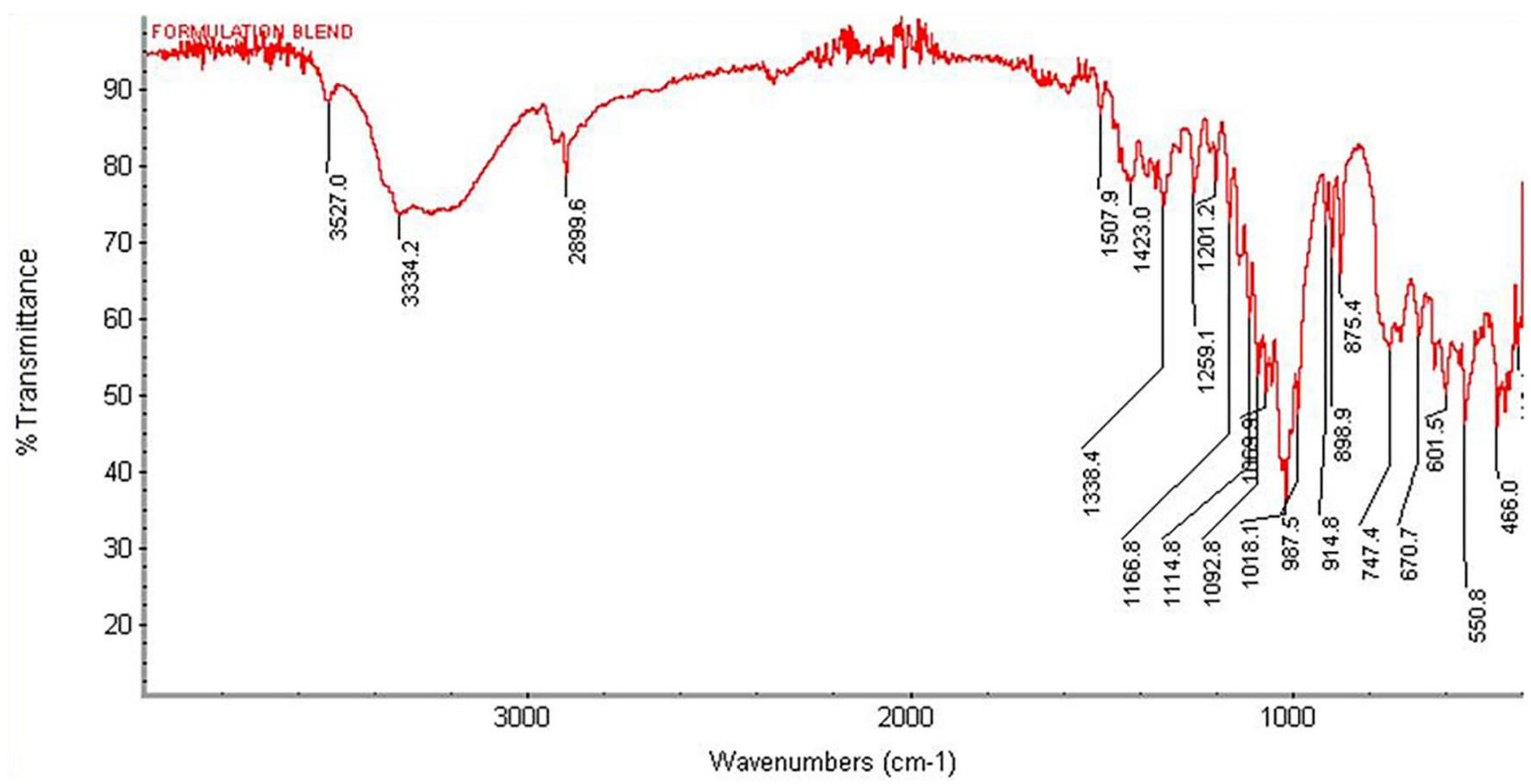

FIGURA 4 - FTIR Spectrum of formulation blend containing diclofenac sodium and Mulva neglecta mucilage.

\section{CONCLUSIONS}

These results showed that in comparison to PVP, the Mulva neglecta mucilage showed better binding capacity. It is concluded from the above study that Mulva neglecta mucilage is safe and can be used as binder in tablets formulation.

\section{REFERENCES}

AKCIN, O.E.; OZBUCAK, T.B. Morphological, anatomical and ecological studies on medicinal and edible plant Malva neglecta Wallr. (Malvaceae). Pak. J. Biol. Sci., v.9, n.14, p.2716-2719, 2006.

BOBBY, M.N.; WESELY, E.A.; JOHNSON, M. FT-IR studies on the leaves of Albizia lebbeck benth. Int. J. Pharm. Pharm. Sci.,v.4, suppl.3, p.293-296, 2012.

CHAKRAVERTY, R. Preparation and evaluation of sustained release microsphere of norfloxacin using sodium alginate. Int. J. Pharm. Sci. Res., v.3, p.293-299, 2011.

COKATE, C.K. Practical pharmacognosy. 4.ed. Delhi: Vallabh Publication Delhi, 2010. 123 p.
GANESH, G.; SURESHKUMAR, R.; JAWAHAR, N.; SENTHIL, V.; VENKATISH, D.N.; SRIVINAS, M.S. Preparation and evaluation of sustained release matrix tablet of diclofenac sodium using natural polymer. J. Pharm. Sci. Res., v.40, p.360-368, 2010.

GUTTI, S.P.; KALRA, M. Formulation and evaluation of sustained release tablets of carvedilol. Int. Res. J. Pharm. App. Sci, v.2, n.4, p.78-83, 2012.

IMTIAZ, B.F.; FOZIA; WAHEED, A.; REHMAN, A.; ULLAH, H.; IQBAL, H., WAHAB, A., ALMAS, M., AHMAD, I. Antimicrobial activity of Mulva neglecta and Nasturtium microphyllum. IJRAP, v.3, n.6, p.808-810, 2012.

MALVIYA, R.; SRIVASTAVA, P.; BANSAL, M.; SHARMA, P.K. Formulation, evaluation and comparison of sustained release matrix tablets of Diclofenac sodium using tamarind gum as release modifier. Asian J. Pharm. Clin. Res., v.3, p.238-241, 2010.

PATEL, V.I.; PATEL, H.A.; JANI, M.; SHAH, A.; KUMAR, S.; PATEL, J.A. Formulation and evaluation of $\mathrm{Okra}$ fruit mucilage as a binder in paracetamol and ibuprofen tablet: antimicrobial activity of Mulva neglecta and Nasturtium microphyllum, v.1, p.156-161, 2012. 
RAHIM, H.; KHAN, M.A.; BADSHAH, A.; CHISHTI, K. A.; KHAN, S.; JUNAID, M. Evaluation of Prunus domestica gum as a novel tablet binder. Braz. J. Pharm. Sci., v.50, n.1, p.195-202, 2014.

RAJESH, K.S.; VENKATARAJU, M.P.; GOWDA, D.V. Effect of hydrophilic natural gums in formulation of oral-controlled release matrix tablets of propranolol hydrochloride. Pak. J. Pharm. Sci., v.22, n.2, p.211-219, 2009.

SATYAM, G.; SHIVANI, S.; GARIMA, G.; NITIN, S.; SHARMA, P.K. Isolation and evaluation of binding property of pappaya starch in diclofenac sodium tablet. Int. J. Pharm. Tech. Res., v.2, p.1508-1512, 2010.

SHAH, G.M.; KHAN, M.A. Checklist of noxious weeds of district Mansehra, Pakistan. Pak. J. Weed Sci. Res., v.12, n.3, p.213-219, 2006.
SHAH, V.; PATEL, R. Studies on mucilage from Hibuscus rosasinensis linn. as oral disintegrant. Int. J. App. Pharm., v.2, n.1, p.18-21, 2010.

SHINGALA, V.K.; SINGH,A.K.; YADAV, S.K.; SIVAKUMAR, T. Design and characterization of Diclofenac sodium tablets containing Mangifera indica resin as release retardant. Int. J. Pharm. Tech. Res., v.2, n.3, p.2107-2111, 2010.

SHIVANAND, P. Instamodel in the development and evaluation of Diclofenac sodium matrix tablet and its effects of release of drug from matrix dosage forms. Int. J. Pharm. Life Sci., v.1, p.241-245, 2010.

ZOHRA, S.F.; M.B.; CHOKRI, B.; MUNEER, A. Evaluation of antifungal activity of some extracts from Mallow. $J$. Microbiol. Biotech. Res, v.2, p.603-605, 2012.

Received for publication on $23^{\text {rd }}$ December 2014 Accepted for publication on $26^{\text {th }}$ August 2015 